\title{
A green approach for the quantification of daptomycin in pharmaceutical formulation by UV spectrophotometry
}

\author{
Eliane Gandolpho Tótoli", Hérida Regina Nunes Salgado
}

\author{
School of Pharmaceutical Sciences, Universidade Estadual Paulista "Júlio de Mesquita Filho", UNESP, \\ Araraquara, SP, Brazil
}

\begin{abstract}
Daptomycin is the first approved drug from a new class of antimicrobials, the cyclic lipopeptides, and is a very important antimicrobial agent in current clinical practice. Currently, there are no "green" analytical methods described in the literature to analyze the typical pharmaceutical dosage form of daptomycin. Thus, the aim of this work was to validate an environment-friendly spectrophotometric method in the UV region, for the analysis of daptomycin as a lyophilized powder. Water was used as diluent and the analyses were carried out on a spectrophotometer at $221 \mathrm{~nm}$. The method met all validation requirements of the ICH guidelines, over a concentration range of 6-21 $\mu \mathrm{g} \mathrm{mL} \mathrm{L}^{-1}$. A Student's t-test demonstrated that the proposed method was comparable to an HPLC method previously validated. Thus, the validated spectrophotometric method could quantify daptomycin in a powder form for injectable solutions, while being an economical, rapid, and "green" alternative for routine analysis in quality control.
\end{abstract}

Uniterms: Antimicrobials/quality control. Daptomycin/determination. Spectrophotometry/UV region/ quantitative analysis. Spectrophotometry/green analytical method.

\begin{abstract}
A daptomicina é o primeiro membro aprovado de uma nova classe de antimicrobianos, os lipopeptídeos cíclicos, e é muito importante para a prática clínica atualmente. Não existem métodos analíticos "verdes" descritos na literatura para a análise da daptomicina na forma farmacêutica. Desta forma, o objetivo deste trabalho foi a validação de método espectrofotométrico na região do UV ambientalmente favorável para análise da daptomicina em pó liofilizado. A água foi escolhida como diluente e as análises foram realizadas em $221 \mathrm{~nm}$. O método atendeu a todas as exigências de validação dos guias do ICH, na faixa de 6-21 $\mu \mathrm{g} \mathrm{mL}^{-1}$. Teste $\mathrm{t}$ de Student mostrou que o método proposto é intercambiável com método de HPLC previamente validado. Assim, o método espectrofotométrico validado é capaz de quantificar a daptomicina em pó para solução injetável e é uma opção econômica, rápida e "verde" para análises de rotina do controle de qualidade deste fármaco.
\end{abstract}

Unitermos: Antimicrobianos/controle de qualidade. Daptomicina/determinação. Espectrofotometria/ região do UV/análise quantitativa. Espectrofotometria/método analítico verde.

\section{INTRODUCTION}

It is widely known that microbial resistance is a major problem worldwide. Many bacteria have developed resistance to a large number of antimicrobial agents available on the market; these bacteria are considered challenges for medicine. Methicillin-resistant Staphylococcus aureus (MRSA) and vancomycin resistant

\footnotetext{
*Correspondence: E. G. Tótoli. Faculdade de Ciências Farmacêuticas. Universidade Estadual Paulista "Júlio de Mesquita Filho" - UNESP. Rodovia Araraquara-Jaú, km 1, 14801-902, Araraquara, SP, Brazil. Phone: 55-16-33016967, Fax: 55-16-33016900. E-mail: eliane.totoli@gmail.com
}

enterococci (VRE) are two examples of antimicrobialresistant microorganisms (Silveira et al., 2006; Wright, 2011). Compounding the problem of antimicrobial resistance, there are few new antimicrobial agents emerging in the market (Wright, 2011).

One recent development in antimicrobial treatment is the introduction of daptomycin into the marketplace (Figure 1). This is the first antimicrobial agent from the cyclic lipopeptide class approved for use in clinical practice in the United States in 2003, and currently in more than 40 countries worldwide (Lopes, 2008; Pirri et al., 2009; Sweetman, 2011). 


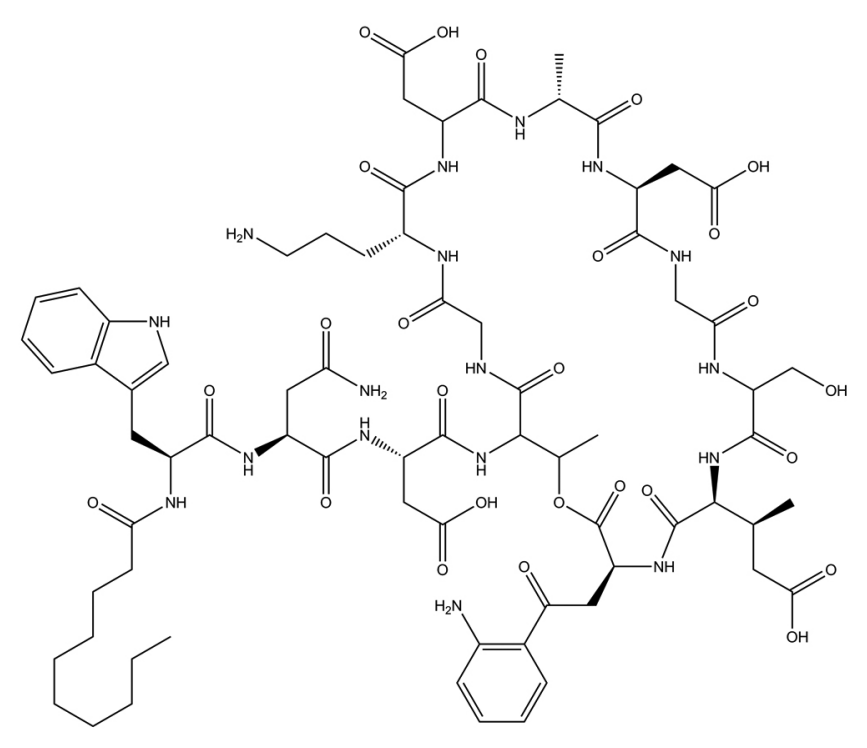

FIGURE 1 - Chemical structure of daptomycin.

Daptomycin has a mechanism of action that is distinct from all other antimicrobial agents available in the market. For this reason, it is able to overcome the mechanisms of resistance that many resistant strains have developed. It has been used successfully in treating some infections caused by resistant gram-positive bacteria, such as MRSA and VRE. Furthermore, resistance to daptomycin is rare worldwide (Silveira et al., 2006; Picazo et al., 2011; Brunton, Chabner, Knollman, 2012; Chitnis et al., 2013; Sader et al., 2014).

The quality of medicines has always been a concern to the World Health Organization (WHO), because without the assurance that these products meet the standards of quality, safety, and efficacy, worldwide health services can be affected. In addition, governments allocate a substantial part of their health budget to purchasing medicines. For these reasons, the WHO advocates for the availability of a reliable system of quality control of medicines in all countries (WHO, 2007). Thus, worldwide interest in research involving medications is increasing, particularly with respect to their quality control. Research that involves the development of new analytical methods is essential to optimize the analysis of medicines in the industry, and guarantees the quality of products already marketed.

In addition to the concern about the quality of analytical data, there is also concern about the environmental impact of industrial activity. Increasingly, companies are seeking environmentally friendly alternatives to their routine processes, adopting a commitment to reducing, preventing, or eliminating harmful waste. There are actions that companies can take to reduce the environmental burden, including the replacement of analytical techniques that employ organic solvents with techniques that do not (Nolasco, Tavares, Bendassoli, 2006).

A few published studies in the literature describe the development of analytical methods to analyze daptomycin. Most of these studies are directed towards biological fluid analysis by high performance liquid chromatography (HPLC), (Tobin et al., 2008; Martens-Lobenhoffer et al., 2008; Baietto et al., 2010; Gika et al., 2010; Olszowy et al., 2010; Polillo et al., 2010; Verdier et al., 2011; Szultka et al., 2013) and ultra-performance liquid chromatography (UHPLC) (Gikas et al., 2010a; Gikas et al., 2010b; Bazoti et al., 2011; Baietto et al., 2014; Naito et al., 2014). In addition, there are no monographs of this drug in any official compendium. One study using HPLC was found in the literature describing an analytical method for the analysis of daptomycin in its pharmaceutical powdered dosage form (Christ et al., 2014).

Most of the reported analytical methods employed techniques that are not considered ecologically friendly in analytical laboratories. Furthermore, the methods that used liquid chromatography require toxic solvents or high volumes of solvents for drug quantification, which is more expensive and unhealthy for the laboratory staff and the community.

Spectrophotometric instrumental methods are considered simple, fast, inexpensive, and reproducible. In addition, they can be developed without the use of organic solvents, which makes this technique more environmentalfriendly (Moreno, Salgado, 2009; Bonfílio, Araújo, Salgado, 2011; Cazedey, Salgado, 2012; Fiorentino, Salgado, 2012; Silva, Almeida, Salgado, 2012; Pedroso, Salgado, 2013; Cazedey, Salgado, 2014; Chierentin, Salgado, 2014; Corrêa, Serra, Salgado, 2014). To our knowledge, there are no studies in the literature that used spectrophotometry to analyze daptomycin.

Considering the importance of daptomycin in clinical practice, and the advantages of spectrophotometric methods, the main objective of the present study was the development of a fast and environmentally friendly ultraviolet (UV) spectrophotometric analytical method for the quantitative analysis of this drug in its lyophilized powder form. As a control, we used a high performance liquid chromatography (HPLC) method, previously developed and validated by our study group, as a comparative method in the determination of this drug.

\section{EXPERIMENTAL}

\section{Equipment}

To perform the spectrophotometric analysis, a 
Shimadzu ${ }^{\mathrm{TM}}$ UV-Vis UV-1800 model spectrophotometer (Shimadzu, Japan) was used. This equipment was connected to a computer loaded with the UV-Probe ${ }^{\mathrm{TM}}$ software. Microsoft Excel (2013) was used to construct the calibration curves. In order to evaluate the robustness of this method, we also used a Shimadzu ${ }^{\mathrm{TM}} \mathrm{UV}$-Vis UV mini-1240 model spectrophotometer (Kyoto, Japan).

For comparative HPLC analysis, we used a model 1525 Waters HPLC (Waters Chromatography systems, USA), connected to a Waters $2487 \mathrm{UV} /$ Visible detector, and a manual injector Rheodyne Breeze $7725 \mathrm{i}$ with a 20 $\mu \mathrm{L}$ loop (Rheodyne Breeze, USA). The chromatographic separation was carried out using isocratic reversed phase conditions on an Agilent Zorbax ${ }^{\mathrm{TM}} \mathrm{C}_{18}, 5 \mu \mathrm{m}, 4.6 \times 150$ mm (Agilent, USA).

The following equipment was also used: $20-200 \mu \mathrm{L}$ micropipettes (Digipet ${ }^{\mathrm{TM}}$, Brazil) and an $\mathrm{H} 51$ analytical scale (Mettler Toledo ${ }^{\mathrm{TM}}$, Switzerland).

\section{Chemicals and reagents}

Daptomycin (DPT) reference standard (DPT RS) (purity of $98.00 \%$ ) was purchased from Sequoia Research Products Company (Sequoia, UK). Samples containing $500 \mathrm{mg}$ of daptomycin, as a lyophilized powder for injectable solution, $\left(\mathrm{Cubicin}^{\mathrm{TM}}\right.$, Novartis, USA) were purchased on the market. The pharmaceutical form contains sodium hydroxide as an excipient. For this reason, sodium hydroxide (Vetec, Brazil) was also used. The solvent used was purified water (obtained by reverse osmosis - Millipore, USA). In order to evaluate the robustness of the method, purified water obtained through Milli-Q Plus equipment (Millipore, USA) was also used.

\section{Spectrophotometric measurements}

UV-Vis spectra of reference and sample solutions were measured using 1-cm quartz cells, and a fast scan speed. Purified water, obtained by reverse osmosis, was used as blank solution for the spectrophotometric measurements. A $221 \mathrm{~nm}$ wavelength was used to develop the present method.

\section{Chromatographic conditions}

In order to compare the results of the proposed spectrophotometric method with a reference method, the same DPT batch was analyzed using an HPLC technique previously developed and validated by our study group. We performed this experiment in isocratic mode, and the mobile phase consisted of ethanol and water (55:45; $\mathrm{v} / \mathrm{v}$ ) with the $\mathrm{pH}$ adjusted to 4.5 using glacial acetic acid. Chromatographic separation was achieved using an Agilent Zorbax ${ }^{\mathrm{TM}} \mathrm{C}_{18}$ analytical column $(150 \times 4.6 \mathrm{~mm}$; $5 \mu \mathrm{m})\left(\right.$ Agilent $^{\mathrm{TM}}$, USA). The volume of the injection was $20 \mu \mathrm{L}$ and the flow rate was $0.6 \mathrm{~mL} \mathrm{~min}^{-1}$. Room temperature was maintained at $25^{\circ} \mathrm{C}$. The peak areas detected at $221 \mathrm{~nm}$ were defined as analytical signs, with detection at $221 \mathrm{~nm}$.

\section{Preparation of solutions}

\section{Stock and working standard solutions}

For the preparation of the DPT RS stock solution, $5.0 \mathrm{mg}$ of DPT RS was weighed, then transferred and diluted with purified water to a volume of $50 \mathrm{~mL}$ in a volumetric flask, yielding a solution with a concentration of $100 \mu \mathrm{g} \mathrm{mL} \mathrm{m}^{-1}$.

Working DPT RS solutions were prepared immediately before use, using purified water to dilute the corresponding stock solution to appropriate concentration levels. For the HPLC analysis, the stock and working standard solutions were diluted with mobile phase.

\section{Stock and working sample solutions}

DPT sample stock solution at a theoretical concentration of $100 \mu \mathrm{g} \mathrm{mL}^{-1}$ was prepared. For this purpose, the average weight of three vials of DPT in powder for injectable solution was calculated. The contents of these vials were mixed, and an amount equivalent to $5.0 \mathrm{mg}$ of DPT was accurately weighted, transferred to the $50-\mathrm{mL}$ volumetric flask, and diluted to $50 \mathrm{~mL}$ with purified water, yielding a stock solution of $100 \mu \mathrm{g} \mathrm{mL}^{-1}$. Appropriate dilutions were made using the same diluent, in order to obtain the working sample solutions. For the HPLC analysis, the stock and working sample solutions were diluted with mobile phase.

\section{Preparation of stock sodium hydroxide solution (placebo)}

A solution containing $1000 \mu \mathrm{g} \mathrm{mL}^{-1}$ of sodium hydroxide was prepared. To prepare the solution, 10 $\mathrm{mg}$ of $\mathrm{NaOH}$ was weighed, transferred to a $10 \mathrm{~mL}$ volumetric flask, and diluted to $10 \mathrm{~mL}$ with purified water. Appropriate dilutions were made using the same diluent, in order to obtain a placebo solution with the correct $\mathrm{NaOH}$ concentration.

\section{Calculation of the DPT content in the sample}

The DPT content in the lyophilized powder sample 
was calculated by using Equation 1 and its percentage content was calculated by using Equation 2.

$$
\begin{array}{cc}
C_{S}=A_{S} \times \frac{C_{R S}}{A_{R S}} & \text { Equation 1 } \\
C_{S} \%=C_{S} \times \frac{100}{C_{t}} & \text { Equation 2 }
\end{array}
$$

where: $\mathrm{C}_{S}=$ concentration of DPT in the sample $\left(\mu \mathrm{g} \mathrm{mL}^{-1}\right)$; $\mathrm{C}_{S} \%=$ percentage concentration of DPT in the sample; $\mathrm{C}_{R S}=$ concentration of DPT RS solution $\left(\mu \mathrm{g} \mathrm{mL}^{-1}\right)$; $\mathrm{A}_{S}=$ absorbance of DPT sample solution; $\mathrm{A}_{R S}=$ absorbance of DPT RS solution; $\mathrm{C}_{t}=$ theoretical concentration of DPT in the sample $\left(\mu \mathrm{g} \mathrm{mL}^{-1}\right)$.

\section{Method validation}

The method was validated by determining the following parameters: linearity, precision, accuracy, robustness, selectivity, detection, and quantification limits, in accordance with recommendations in the literature (ICH, 2005; ANVISA, 2010; USP, 2014).

\section{Linearity}

In order to analyze the linearity of the method, three analytical curves, performed on three different days, were evaluated. For this purpose, aliquots of $0.3,0.45$, $0.6,0.75,0.9$, and $1.05 \mathrm{~mL}$ of the stock DPT standard solution were transferred to $5 \mathrm{~mL}$ volumetric flasks, and diluted to $5 \mathrm{~mL}$ with purified water. This resulted in DPT RS working solutions with concentrations of 6.0, 9.0, 12.0, 15.0, 18.0, and $21.0 \mu \mathrm{g} \mathrm{mL}^{-1}$. Each concentration was prepared in triplicate $(\mathrm{n}=3)$ and spectrophotometric analysis was conducted at a wavelength of $221 \mathrm{~nm}$. The results were evaluated by linear regression analysis, which was calculated by the least square method, and the linearity was verified by analysis of variance (ANOVA).

\section{Precision}

Accuracy of the method was evaluated in two different ways: by repeatability and intermediate precision. Repeatability (or intraday precision) was assessed by the analysis of DPT RS working solutions $(\mathrm{n}=6)$ at a concentration of $12.0 \mu \mathrm{g} \mathrm{mL}^{-1}$, which were prepared and analyzed on the same day and under similar experimental conditions. The percent relative standard deviation (RSD\%) of the measurements was calculated and evaluated. Intermediate precision (inter-day and between different analysts) was evaluated by determining DPT content in the samples of lyophilized powder on three different days, and by a second analyst, under the same experimental conditions. $\mathrm{RSD} \%$ values were calculated between the determinations (ICH, 2005).

\section{Accuracy}

Accuracy of the method was determined by measuring the reference standard recovery in triplicate at three levels (R1, R2 and R3), from 80 to $120 \%$ of the method concentration $\left(12.0 \mu \mathrm{g} \mathrm{mL}^{-1}\right)$, according to ICH recommendations ( $\mathrm{ICH}, 2005)$. For this purpose, the stock solutions of DPT RS and DPT as a powder for injectable solution $\left(100 \mu \mathrm{g} \mathrm{mL}^{-1}\right)$ were prepared as described in previous sections. From the sample stock solution, aliquots of $0.30 \mathrm{~mL}$ were transferred to three 5 $\mathrm{mL}$ volumetric flasks. Then aliquots of $0.18,0.30$, and $0.42 \mathrm{~mL}$ from the DPT RS stock solution were added. The flasks were then filled with purified water, obtaining solutions with concentrations of 9.6, 12.0, and $14.4 \mu \mathrm{g}$ $\mathrm{mL}^{-1}$, which is equivalent to 80 (R1), 100 (R2), and $120 \%$ (R3) of the working concentration. The mean recoveries, expressed in terms of percent recovery from the pharmaceutical dosage form (Cubicin ${ }^{\mathrm{TM}} 500 \mathrm{mg}$ ) by the assay, and the respective relative standard deviation (R.S.D.), were calculated using the equation described by the Association of Analytical Chemists (AOAC) (AOAC, 2002).

\section{Robustness}

In order to evaluate the robustness of the method, the following parameters were individually altered: wavelength (measured at 219 and $223 \mathrm{~nm}$ ), spectrophotometer (tested with a Shimadzu ${ }^{\mathrm{TM}}$ UV mini1240 model), and an alternative source of water (Milli-Q water). Robustness was evaluated by performing DPT content determinations in the sample of lyophilized powder under the different conditions. The DPT content calculated under the modified conditions was compared with the results obtained under the normal working conditions, according to the RSD\% between the results.

\section{Selectivity}

In order to evaluate the selectivity of the method, a spectrum obtained with DPT RS solution at a concentration of $12 \mu \mathrm{g} \mathrm{mL} \mathrm{mL}^{-1}$ was compared with the spectrum obtained with a placebo solution. This determined whether there was any interference from placebo in the DPT analysis.

The DPT RS solution was prepared as described in previous sections. The placebo solution, in turn, was prepared using sodium hydroxide, as it is the only other constituent of the DPT sample excipient. A concentration of $1.03 \mu \mathrm{g} \mathrm{mL}^{-1}$ was used, equivalent to the 
concentration of $\mathrm{NaOH}$ present in $12 \mu \mathrm{g} \mathrm{mL} \mathrm{mL}^{-1}$ solution of DPT in lyophilized powder. This percentage of $\mathrm{NaOH}$ was calculated according to the average weight of three vials of DPT as a powder for injectable solution. To conduct this test, an aliquot of $51.5 \mu \mathrm{L}$ from the stock placebo solution at $1000 \mu \mathrm{g} \mathrm{mL}^{-1}$ was transferred to a $50 \mathrm{~mL}$ volumetric flask, the volume was adjusted to $50 \mathrm{~mL}$ with purified water, and then the solution was adequately homogenized.

DPT RS and placebo solutions were spectrophotometrically analyzed in the UV region (200$400 \mathrm{~nm}$ ) and their absorption spectra were compared.

\section{Detection and quantification limits}

Detection and quantification limits were calculated based on the intercept standard deviations, and the curve inclinations from the linear regression, as described in the literature (ICH, 2005).

\section{Comparison of methods}

In order to compare the spectrophotometric and chromatographic methods, DPT sample content determinations were performed using both methods. The results of the determinations obtained by spectrophotometry in the UV region were statistically compared with those obtained with the HPLC method, using a Student's t test at a level of significance of $p<0.05$.

\section{RESULTS AND DISCUSSION}

\section{General aspects and method development}

Fast and practical analytical methods to quantify daptomycin in either the pharmaceutical dosage form or other forms have not been previously published. The existing methods to analyze this important antimicrobial agent require large volumes of organic solvents and sophisticated equipment. In addition, most of these methods analyze daptomycin in biological fluids, rather than the pharmaceutical dose. In this study, water was chosen as the diluent, since it is inexpensive and not hazardous to laboratory staff or the environment; the choice of this diluent makes the present method economical, safe, practical, and environmental-friendly.

In a recent literature search, an excellent paper detailing the advances made in green pharmaceutical research was discovered (Cue, Zhang, 2009). In this paper, the authors expressed hope, and had high expectations, that the concepts presented will lead to new ecological methodologies to quantify drugs. They discuss case studies of the successful modification of processes to achieve reduced resource requirements, waste generation, or energy consumption. The authors also expressed hope that there will be increased emphasis on green chemistry in pharmaceutical research and manufacturing. In response to environmental concerns, pharmaceutical researchers have concentrated their focus and creative energies towards minimizing and optimizing the environmental impact of their craft. Therefore, with many compounds in queue for therapeutic screening, ecologically friendly changes to the standard processes and current analytical methods that allow for increased throughput are welcome.

To develop the current method, DPT RS UV spectra were obtained in multiple solvents to confirm the suitability of water as a diluent. DPT RS was observed to be soluble in all tested solvents (water, methanol, $0.1 \mathrm{~mol} \mathrm{~L}^{-1} \mathrm{NaOH}$ and $\left.0.1 \mathrm{~mol} \mathrm{~L}^{-1} \mathrm{HCl}\right)$; the spectra are presented in Figure 2.

The maximum absorption wavelength was $221 \mathrm{~nm}$ when using water as a diluent. The wavelength was slightly lower, at $220.2 \mathrm{~nm}$, when $0.1 \mathrm{~mol} \mathrm{~L}^{-1} \mathrm{HCl}$ was used as the diluent. The other two solvents tested as diluents, methanol and $0.1 \mathrm{~mol} \mathrm{~L}^{-1} \mathrm{NaOH}$, had maximum absorptions at 223.6 and $223.0 \mathrm{~nm}$, respectively. The spectra obtained with $0.1 \mathrm{~mol} \mathrm{~L}^{-1} \mathrm{NaOH}$ and $0.1 \mathrm{~mol} \mathrm{~L}^{-1} \mathrm{HCl}$ had a lower absorption peak at the maximum absorption wavelength, suggesting DPT degradation.

Since the spectra were similar between water and methanol, water was chosen as the diluent in the validation of this quantitative method, owing to its economic and environmental advantages. The use of water as a diluent is very relevant to the pharmaceutical industries, since analytical methods that do not use organic solvents for analysis are sought after in order to reduce the impacts of their activities on the environment.

\section{Method validation}

Linearity

Three calibration curves, generated on three separate days, were constructed by plotting the average absorbances at $221 \mathrm{~nm}$ with respect to the concentrations. The final analytical curve, constructed using the average of the three analytical curves, yielded a correlation coefficient (r) greater than 0.999 (Table I).

A linear correlation between the DPT RS concentrations and the respective mean absorbances was observed within the studied range. The correlation coefficient value indicates the high degree of linearity using this method.

In addition, the data were validated using analysis of variance (ANOVA), which revealed significant linear 

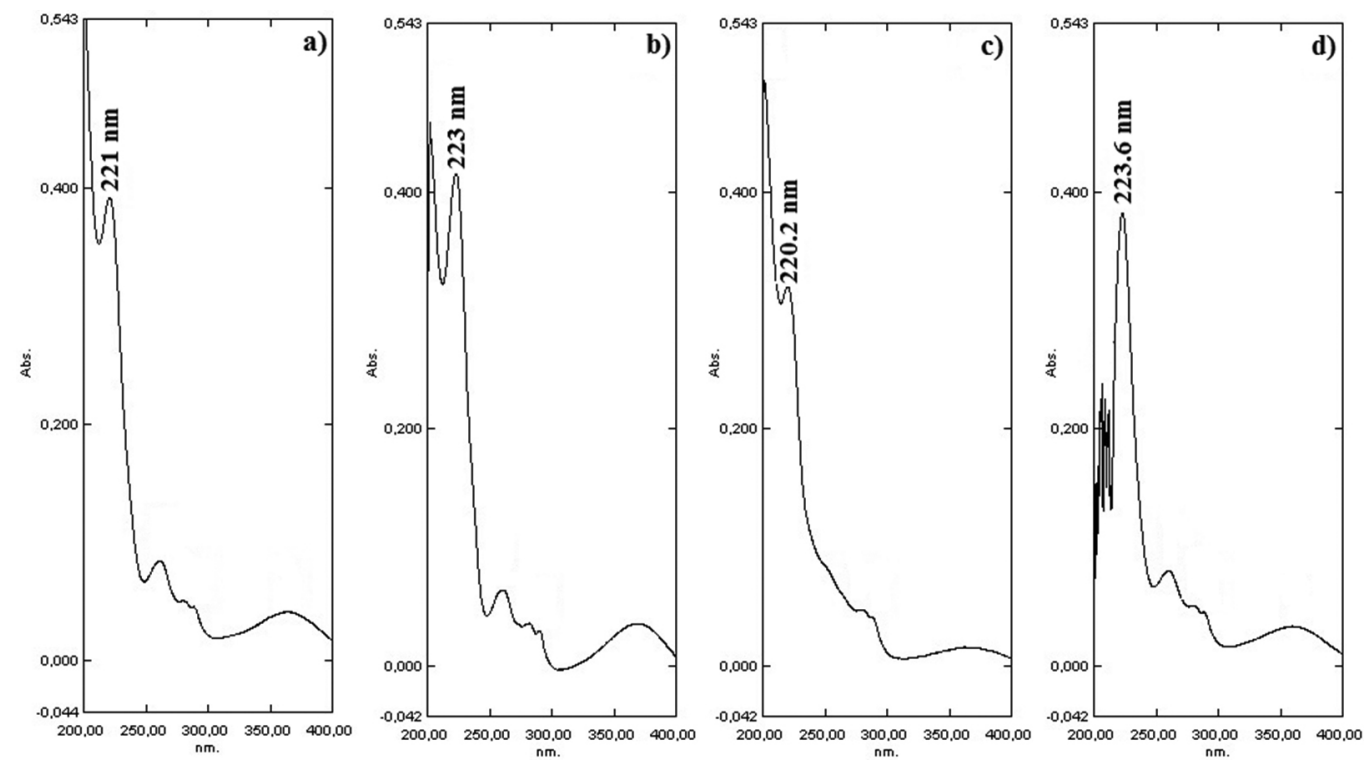

FIGURE 2 - Ultraviolet absorption spectra of DPT RS solution at a concentration of $12 \mu \mathrm{g} \mathrm{mL}^{-1}$. The DPT RS was dissolved using the following diluents: a) water; b) methanol; c) $0.1 \mathrm{~mol} \mathrm{~L}^{-1} \mathrm{HCl}$ and d) $0.1 \mathrm{~mol} \mathrm{~L}^{-1} \mathrm{NaOH}$.

TABLE I - Linearity parameters for the determination of DPT

\begin{tabular}{lc}
\hline Parameter & Result \\
\hline Linearity range $\left(\mu \mathrm{g} \mathrm{mL}^{-1}\right)$ & 6.0 to 21.0 \\
Slope & $0.0299 \pm 0.0003^{\mathrm{a}}$ \\
Intercept & $0.0095 \pm 0.0013^{\mathrm{a}}$ \\
Correlation coefficient & $0.9999 \pm 0.0003^{\mathrm{a}}$ \\
\hline
\end{tabular}

${ }^{a}$ Values are reported as mean \pm standard deviation (S. D.) of three analytical curves generated on three consecutive days $(\mathrm{n}=3)$.

regression, since the $\mathrm{F}_{\text {calculated }}(18820.25)$ was higher that the $\mathrm{F}_{\text {critical }}(4.75)$, while no significant linearity deviation was detected, since the $\mathrm{F}_{\text {calculated }}(0.33)$ was lower than the $\mathrm{F}_{\text {critical }}(3.26)$. This analysis was performed at a significance level of $5 \%(p<0.05)$.

\section{Precision}

The precision of the method was evaluated in two different ways: repeatability (intraday precision) and intermediate precision (interdays and inter-analyst precisions). The intermediate precision results are presented in Table II. The intraday precision $(n=6)$ gave an RSD value of $1.20 \%$.

The RSD\% values observed were lower than $1.20 \%$, which confirms the appropriate precision of the method.

\section{Accuracy}

The accuracy of the method was determined using a recovery assay performed at three different concentration levels (Table III). The data demonstrates adequate accuracy of the method, since the experimental concentrations were very close to the real values (close to $100 \%$ ).

\section{Robustness}

Robustness of the method was determined, demonstrating the reliability of the analysis regarding small variations in the working parameters. The results

TABLE II - Intermediate precision of the spectrophotometric method to determine DPT content

\begin{tabular}{|c|c|c|c|c|c|c|c|c|}
\hline \multicolumn{5}{|c|}{ Interdays } & \multicolumn{4}{|c|}{ Between analysts } \\
\hline Sample & Day & $\begin{array}{c}\text { Content }^{\mathrm{a}}(\mathrm{g} / \\
\text { vial) }\end{array}$ & $\begin{array}{c}\text { Content }^{\mathrm{a}} \\
(\%)\end{array}$ & RSD (\%) & Analyst & $\begin{array}{c}\text { Content }^{\mathrm{a}}(\mathrm{g} / \\
\text { vial) }\end{array}$ & $\begin{array}{c}\text { Content }^{\mathrm{a}} \\
(\%)\end{array}$ & RSD (\%) \\
\hline \multirow{3}{*}{1} & 1 & 0.517 & 103.45 & & 1 & 0.519 & 103.74 & \multirow{3}{*}{0.13} \\
\hline & 2 & 0.514 & 102.76 & 1.11 & 2 & 0.518 & 103.55 & \\
\hline & 3 & 0.525 & 105.02 & & & & & \\
\hline
\end{tabular}

a mean of three determinations $(\mathrm{n}=3)$ 
TABLE III - Accuracy of the spectrophotometric method for the determination of DPT concentration

\begin{tabular}{lccccc}
\hline & $\begin{array}{c}\text { Added DPT RS / } \mu \mathrm{g} \\
\mathrm{mL}^{-1}\end{array}$ & $\begin{array}{c}\mathrm{DPT} \mathrm{RS} \mathrm{found}^{\mathrm{a}} / \\
\mu \mathrm{g} \mathrm{mL}^{-1}\end{array}$ & $\begin{array}{c}\text { Recovery } \\
(\%)\end{array}$ & $\begin{array}{c}\text { RSD (\%) } \\
(\mathrm{n}=3)\end{array}$ & $\begin{array}{c}\text { Average recovery } \\
(\%)\end{array}$ \\
\hline $\mathbf{R 1}$ & 3.60 & 3.60 & 100.01 & 1.43 & \\
$\mathbf{R 2}$ & 6.00 & 5.97 & 99.58 & 0.03 & 99.94 \\
$\mathbf{R 3}$ & 8.40 & 8.42 & 100.23 & 1.06 & \\
\hline
\end{tabular}

${ }^{\mathrm{a}}$ average of three determinations.

TABLE IV - Robustness of the spectrophotometric method for determining DPT concentration

\begin{tabular}{|c|c|c|c|c|}
\hline Variable & Range investigated & $\begin{array}{l}\text { Content } \\
\text { (g/vial) }\end{array}$ & $\begin{array}{c}\text { Content } \\
(\%)\end{array}$ & $\operatorname{RSD}(\%)$ \\
\hline \multirow{3}{*}{ Wavelenght (nm) } & 219 & 0.514 & 102.89 & \multirow{3}{*}{0.56} \\
\hline & $221^{\mathrm{a}}$ & 0.519 & 103.74 & \\
\hline & 223 & 0.513 & 102.63 & \\
\hline \multirow{2}{*}{ Spectrophotometer } & $\begin{array}{l}\text { UV-Vis Shimadzu } \\
\text { UV-1800 } \text { model }^{\mathrm{TM}}\end{array}$ & 0.519 & 103.74 & \multirow{2}{*}{0.81} \\
\hline & $\begin{array}{l}\text { UV-Vis Shimadzu }{ }^{\mathrm{TM}}, \mathrm{UV} \\
\text { mini-1240 model }\end{array}$ & 0.513 & 102.57 & \\
\hline \multirow{2}{*}{ Source of water } & Reverse osmosis ${ }^{\mathrm{a}}$ & 0.519 & 103.74 & \multirow{2}{*}{0.01} \\
\hline & Milli-Q & 0.519 & 103.76 & \\
\hline
\end{tabular}

${ }^{a}$ Standard working conditions.

show that the validity of the method was maintained, even with small variations in the method's working conditions (Table IV) (ICH, 2005).

The calculated RSD $\%$ values were below $0.81 \%$, proving that small variations in the working conditions will not interfere with the analysis of DPT.

\section{Selectivity}

Figure 3 (a) shows the overlap of the spectra obtained with DPT RS solution and placebo solution $(\mathrm{NaOH})$. Figure 3 (b) shows the overlap of the spectra obtained with DPT RS and lyophilized powder solutions. It was observed that the formulation excipient of the DPT in lyophilized powder did not interfere with the UV spectrophotometric method, since the excipient did not have any absorption bands that may have interfered with the analysis of DPT, in the wavelength used in this method. Thus, the selectivity of the method was confirmed.

\section{Detection and quantification limits}

The limits of detection (LOD) and quantification (LOQ) were calculated to determine the sensitivity of the method. The calculated value for the LOD was $0.14 \mu \mathrm{g}$ $\mathrm{mL}^{-1}$ and the LOQ was $0.42 \mu \mathrm{g} \mathrm{mL}^{-1}$. These values indicate
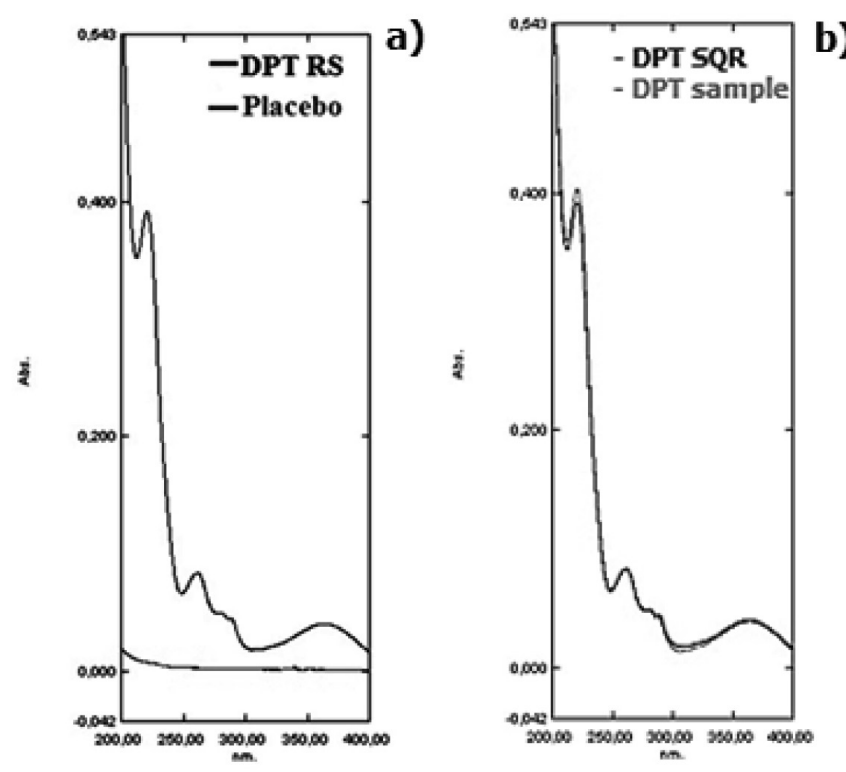

FIGURE 3 - a) Overlap of the absorption spectra of DPT RS $\left(12 \mu \mathrm{g} \mathrm{mL}^{-1}\right)$ and placebo $(\mathrm{NaOH})$ solutions, using water as the solvent; b) Overlap of the absorption spectra of DPT RS $\left(12 \mu \mathrm{g} \mathrm{mL}^{-1}\right)$ and lyophilized powder $\left(12 \mu \mathrm{g} \mathrm{mL}^{-1}\right)$ solutions, using water as the solvent.

the ability of this method to reliably detect and quantify DPT in its pharmaceutical dosage form. 
Assay of the pharmaceutical product and comparison between methods

The comparison between analytical methods is an important tool to determine if the procedures are equivalent. Thus, in order to compare the spectrophotometric method proposed in this work with a previously validated HPLC method, statistical analysis of the DPT content (as a lyophilized powder) was performed using Student's t test $(p<0.05)$. The percentage contents of daptomycin calculated using both methods are shown in Table V.

TABLE V - Values obtained in the determination of DPT as a lyophilized powder for injectable solution, by HPLC and UV spectrophotometry

\begin{tabular}{lcc}
\hline \multirow{2}{*}{ Parameters } & \multicolumn{2}{c}{ Method } \\
\cline { 2 - 3 } & HPLC $^{\mathrm{a}}$ & $\mathrm{UV}^{\mathrm{b}}$ \\
\hline DPT content (\%) & 104.37 & 103.45 \\
& 101.90 & 102.76 \\
Average content (\%) & 100.89 & 102.57 \\
\hline
\end{tabular}

${ }^{a}$ HPLC: high-performance liquid chromatography; ${ }^{b} \mathrm{UV}$ : spectrophotometry in UV region

Statistical analysis revealed that the DPT contents determined by both methods were statistically equivalent, since the $t_{\text {calculated }}(0.51)$ was lower than the $t_{\text {critical }}(2.78)$. Thus, these methods are interchangeable for the quantitative analysis of daptomycin in the pharmaceutical dosage form.

Although the statistical analysis demonstrated that both techniques are interchangeable, there are a number of differences between these methods to take into account when considering their advantages and disadvantages.

HPLC is one of the most commonly used techniques for the quantitative analysis of drugs in the pharmaceutical industry. This method presents some advantages, such as the ability to perform analysis in a short time, the ability to analyze complex mixtures owing to its high resolution, easy and accurate quantitative analysis, good sensitivity, and versatility, since it allows the analysis of a wide range of substances. In addition, it allows for the automation of analysis, making it convenient to conduct to routine analysis. On the other hand, one of the major disadvantages is the high cost of instrumentation and operation, since this technique requires expensive chromatographic columns and high-purity organic solvents (Collins, Braga, Bonato, 1997). Additionally, this technique uses large volumes of organic solvents for analysis, which makes it a source of occupational exposure and environmental contamination.
In contrast, UV spectrophotometry, in many cases, can be developed in an environmental-friendly way without the use of organic solvents, as demonstrated in the present work. However, even when the use of organic solvents is necessary, this technique is still advantageous when compared to HPLC, since it requires smaller amounts of organic solvents than the chromatographic method. As the UV spectrophotometry method does not require the use of costly chromatographic columns and high purity solvents, this technique is also economically advantageous. This cost advantage is even greater when the method uses water as the diluent, as it is a low cost solvent. Another advantage of this technique is the short time to conduct analysis, which makes it a practical option for routine analysis in quality control. However, one downside of UV spectrophotometry is that it is not able to detect and separate degradation products, unlike the HPLC.

\section{CONCLUSION}

In the present study, the UV spectrophotometric analytical method was properly developed, validated, and shown to be effective for the quantification of daptomycin in its pharmaceutical dosage form as a lyophilized powder for injectable solution. This method has advantages when compared to chromatographic methods, such as employing an aqueous system, rather than potentially toxic organic solvents, and it requires minimal sample preparation steps. In addition, spectrophotometric analysis uses small amounts of solvents and sample, resulting in a nonpolluting method for staff and the environment.

This procedure uses simple reagents, requires minimal sample preparation, and generates only a small amount of residue. Therefore, its use is encouraged for routine analysis. The proposed method might be successfully used in the quantitative analysis of pharmaceutical formulations of daptomycin, contributing to improvements in medication quality control. In addition, a Student's t-test showed no statistically significant difference between the proposed UV spectrophotometric method and a previously validated HPLC method. Given these results, both methods are interchangeable, however the spectrophotometric method is environmentally and economically advantageous compared to the HPLC method.

\section{ACKNOWLEDGEMENTS}

This work was supported by FAPESP (São Paulo, Brazil), PADC-FCF (São Paulo, Brazil), and CNPq 
(Brasília, Brazil). E.G. Tótoli was funded by FAPESP(São Paulo, Brazil) and H.R.N. Salgado was funded by CNPq (Brasília, Brazil).

\section{REFERENCES}

AGÊNCIA NACIONAL DE VIGILÂNCIA SANITÁRIA. ANVISA. Farmacopeia Brasileira. 5. ed. Brasília: Anvisa, 2010. v.I, p.261-269; v.II, p.75-87.

ASSOCIATION OF OFFICIAL ANALYTICAL CHEMISTS. AOAC. Official methods of analysis. 17. ed. Gaithesburg, MD: AOAC, 2002. $2 \mathrm{v}$.

BAIETTO, L.; D’AVOLIO, A.; PACE, S.; SIMIELE, M.; MARRA, C.; ARIAUDO, A.; PERRI, G.D.; ROSA, F.G.D. Development and validation of an UPLC-PDA method to quantify daptomycin in human plasma and in dried plasma spots. J. Pharm. Biomed. Anal., v.88, p.66-70, 2014.

BAIETTO, L.; D'AVOLIO, A.; ROSA, F.G.; GARAZZINO, S.; MICHELAZZO, M.; VENTIMIGLIA. G.; SICCARDI, M.; SIMIELE, M.; SCIANDRA, M.; PERRI, G. Development and validation of a simultaneous extraction procedure for HPLC-MS quantification of daptomycin, amikacin, gentamicin, and rifampicin in human plasma. Anal. Bioanal. Chem., v.396, n.2, p.791-798, 2010.

BAZOTI, F.N.; GIKAS, E.; SKOUTELIS, A.; TSARBOPOULOS, A. Development and validation of an ultra performance liquid chromatography-tandem mass spectrometry method for the quantification of daptomycin in human plasma. J. Pharmaceut. Biomed. Anal., v.56, n.1, p.78-85, 2011.

BONFILIO, R.; ARAÚJO, M.B.; SALGADO, H.R.N.J. Development and validation of an UV-derivative spectrophotometric method for determination of glimepiride in tablets. J. Brazil. Chem. Soc., v.22, n.2, p.292-299, 2011.

BRUNTON, L.L.; CHABNER, B.A.; KNOLLMAN, B.B.(Eds.) Goodman \& Gilman: As bases farmacológicas da terapêutica. 12. ed. São Paulo: AMGH, 2012. 2079 p.

CAZEDEY, E.C.L.; SALGADO, H.R.N. A first-derivative spectrophotometric method for the determination of ciprofloxacin hydrochloride in ophthalmic solution. Phys. Chem., v.2, p.116-122, 2012.
CAZEDEY, E.C.L.; SALGADO, H.R.N. Development and validation of UV spectrophotometric method for orbifloxacin assay and dissolution studies. Braz. J. Pharm. Sci., v.50, n.3, p.457-465, 2014.

CHIEREnTIN, L.; SALGADO, H.R.N. Performance characteristics of UV and visible spectrophotometry methods for quantitative determination of norfloxacin in tablets. J. Sci. Res., v.6, p.531-541, 2014.

CHITNIS, S.; KATARA, G.; HEMVANI, N.; PAREEK, S.; CHITNIS, D.S. In vitro activity of daptomycin \& linezolid against methicillin resistant Staphylococcus aureus \& vancomycin resistant enterococci isolated from hospitalized cases in Central India. Indian J. Med. Res., v.137, n.1, p.191-196, 2013.

CHRIST, A.P.; MACHADO, M.S.; ROSA, P.; CODEVILLA, C.F.; ROLIM, C.M.B.; ADAMS, A.I.H. Development and validation of a stability-indication LC-UV method for determination of daptomycin injectable form and kinetic study in alkaline medium. Anal. Methods, v.6, p.12421247,2014

COLLINS, C.H.; BRAGA, G.L.; BONATO, P.S. Introdução a métodos cromatográficos. 7. ed. Campinas: Editora UNICAMP, 1997.

CORREAA, J.C.R.; SERRA, C.H.R.; SALGADO, H.R.N. Development and validation of first derivative spectrophotometric method for quantification of darunavir in tablets. B. J. Pharm. Res., v.4, p.722-730, 2014.

CUE, B.W.; ZHANG, J. Green process chemistry in the pharmaceutical industry. Green Chem. Lett. Rev., v.2, p.193-211, 2009.

FIORENTINO, F.A.M.; SALGADO, H.R.N. Development and validation of a UV-spectrophotometric method for determination of flucloxacillin sodium in capsules. Curr. Pharm. Anal., v.8, p.101-106, 2012.

GIKA, H.G.; MICHOPOULOS, F.; DIVANIS, D.; METALIDIS, S.; NIKOLAIDIS, P.; THEODORIDIS, G.A. Daptomycin determination by liquid chromatography-mass spectrometry in peritoneal fluid, blood plasma, and urine of clinical patients receiving peritoneal dialysis treatment. Anal. Bioanal. Chem., v.397, n.6, p.2191-2197, 2010. 
GIKAS, E.; BAZOTI, F.N.; FANOURGIAKIS, P.; PERIVOLIOTI, E.; ROUSSIDIS, A.; SKOUTELIS, A.; TSARBOPOULOS, A. Development and validation of a UPLC-UV method for the determination of daptomycin in rabbit plasma. Biomed. Chromatogr., v.24, n.5, p.522-527, 2010a.

GIKAS, E.; BAZOTI, F.N.; FANOURGIAKIS, P.; PERIVOLIOTI, E.; ROUSSIDIS, A.; SKOUTELIS, A.; TSARBOPOULOS, A. Simultaneous quantification of daptomycin and rifampicin in plasma by ultra performance liquid chromatography: Application to a pharmacokinetic study. J. Pharm. Biomed. Anal., v.51, n.4, p.901-906, 2010 b.

INTERNATIONAL CONFERENCE ON HARMONIZATION. ICH. Validation of analytical procedures: Text and Methodology Q2 (R1). Geneva, 2005.

LOPES, H.V. Daptomicina: finalmente disponível para a América do Sul. Rev. Panam. Infectol., v.10, n.3, p.70-71, 2008.

MARTENS-LOBENHOFFER, J.; KIELSTEIN, J.T.; OYE, C.; BODE-BÖGER, S.M. Validated high performance liquid chromatography-UV detection method for the determination of daptomycin in human plasma. $J$. Chromatogr. B, v.875, n.2, p.546-550, 2008.

MORENO, A.H.; SALGADO, H.R.N. Rapid and selective UV spectrophotometric method for the analysis of ceftazidime. J. AOAC Int., v.92, n.3, p.820-823, 2009.

NAITO, T.; YAMADA, T.; YAGI, T.; KAWAKAMI, J. Simple and validated UHPLC method coupled to UV detection for determination of daptomycin in human plasma and urine. Biomed. Chromatogr., v.28, n.3, p.317-319, 2014.

NOLASCO, F.R.; TAVARES, G.A.; BENDASSOLLI, J.A. Implantação de programas de gerenciamento de resíduos químicos laboratoriais em universidades: análise crítica e recomendações. Eng. Sanit. Ambient., v.11, p.118-124, 2006.

OLSZOWY, P.; SZULTKA, M.; FUCHS, P.; KEGLER, R.; MUNDKOWSKI, R.; MIEKISCH, W.; SCHUBERT, J.; BUSZEWSKI, B. New coated SPME fibers for extraction and fast HPLC determination of selected drugs in human blood. J. Pharm. Biomed. Anal., v.53, n.4, p.1022-1027, 2010
PEDROSO, T.M.; SALGADO, H.R.N. Validation of cefazolin sodium by UV-spectrophotometric method. Phys. Chem., v.3, p.11-20, 2013.

PICAZO, J.J.; BETRIU, C.; CULEBRAS, E.; RODRÍGUEZAVIAL, I.; GÓMEZ, M.; LÓPEZ-FABAL, F. Staphylococcus aureus resistente a meticilina: sensibilidad a la daptomicina a lo largo de un periodo de 10 años (20012010). Rev. Esp. Quimioter., v.24, p.107-111, 2011.

PIRRI, G.; GIULIANI, A.; NICOLETTO, S.F.; PIZZUTO, L.; RINALDI, A.C. Lipopeptides as anti-infectives: a practical perspective. Cent. Eur. J. Biol., v.4, n.3, p.258-273, 2009.

POLILLO, M.; TASCINI, C.; LASTELLA, M.; MALACARNE, P.; CIOFI, L.; VIAGGI, B.; BOCCI, G.; MENICHETTI, F.; DANESI, R.; DEL TACCA, M.; DI PAOLO, A. A rapid high-performance liquid chromatography method to measure linezolid and daptomycin concentrations in human plasma. Ther. Drug Monit., v.32, n.2, p.200-205, 2010.

SADER, H.S.; FARRELL, D.J.; FLAMM, R.K.; JONES, R.N. Daptomycin activity tested against 164.457 bacterial isolates from hospitalised patients: Summary of 8 years of a Worldwide Surveillance Programme (2005-2012). Int. J. Antimicrob. Agents, v.43, p.465-469, 2014.

SILVA, L.M.; ALMEIDA, A.E.; SALGADO, H.R.N. Thermal analysis and validation of UV and visible spectrophotometric methods for the determination of new antibiotic tigecycline in pharmaceutical product. Adv. Anal Chem., v.2, p.10-15, 2012.

SILVEIRA, G.P.; NOME, F.; GESSER, J.C.; SÁ, M.M.; TERENZI, H. Estratégias utilizadas no combate à resistência bacteriana. Quim. Nova, v.29, n.4, p.844-855, 2006.

SWEETMAN, S.C. (Ed). Martindale: the complete drug reference. 37. ed. London: RPS Publishing, 2011. 4142 p.

SZULTKA, M.; KRZEMINSKI, R.; JACKOWSKI, M.; BUSZEWSKI, B. Simultaneous determination of selected chemotherapeutics in human whole blood by molecularly imprinted polymers coated solid phase microextraction fibers and liquid chromatography-tandem mass spectrometry. J. Chromatogr. B, v.940, p.66-76, 2013.

TOBIN, C.M.; DARVILlE, J.M.; LOVERING, A.M.; MACGOWAN, A.P. An HPLC assay for daptomycin in serum. J. Antimicrob. Chemother., v.62, p.1462-1476, 2008. 
UNITED STATES PHARMACOPEIA. USP. The United States Pharmacopeia. 37.ed. Rockville, MD: United States Pharmacopoeia Convention, 2014.

VERDIER, M.-C.; BENTUÉ-FERRER, D.; TRIBUT, O.; COLLET, N.; REVEST, M.; BELlisSANT, E. Determination of daptomycin in human plasma by liquid chromatography-tandem mass spectrometry. Clin. Chem. Lab. Med., v.49, n.1, p.69-75, 2011.
WORLD HEALTH ORGANIZATION. WHO. Quality assurance of pharmaceuticals: a compendium of guidelines and related materials. 2. ed. Geneva: Good Manufacturing Practices and Inspection, 2007. v.2

WRIGHT, G.D. Molecular mechanisms of antibiotic resistance. Chem. Commun., v.47, p.4055-4061, 2011.

Received for publication on $23^{\text {th }}$ March 2015 Accepted for publication on $02^{\text {nd }}$ July 2015 
